\title{
Forum
}

\section{If community conservation is the answer in Africa, what is the question?}

\author{
W. M. Adams and D. Hulme
}

\begin{abstract}
Proponents of community conservation present it as a means of reconciling conservation and development objectives by ensuring that the interests of local people are taken into account in making trade-offs. Conservation critics see it as a challenge to the state-led, scientific management that is necessary to guarantee the preservation of biodiversity. In this paper, we argue that community conservation is not one thing but many. It is evolving both as a concept and as a practice that must be
\end{abstract}

\section{Introduction}

Inamdar et al. (1999) point out that purely protectionist approaches to biodiversity conservation have become widely unpopular, not least with the international conservation community, and that traditional protected areas (PAs) are suffering from a public relations crisis. The causes of this crisis include the high economic costs of 'fences and fines' approaches to conservation (LeaderWilliams \& Albon, 1988), the low economic returns from protected areas compared with alternative humansettled land uses (Norton-Griffiths \& Southey, 1995), and the strength of political voices claiming that the exclusion of local people from parks is variously unfair, unreasonable and/or illegal (Neumann, 1998).

We have argued elsewhere that this disenchantment with 'fortress conservation' has indeed been profound in the global conservation movement, and that there has been a significant shift in the dominant 'narrative' of conservation (Adams \& Hulme, 1998, 2001; cf. Leach \& Mearns, 1996). The new 'conservation narrative' is 'community conservation' (hereafter ' $\mathrm{CC}$ '): the notion that conservation cannot and should not be pursued against the interests and wishes of local people (e.g. Ghimire \& Pimbert, 1996). This narrative has itself become so widely adopted that it is now almost everywhere dominant, the obvious answer to the

W. M. Adams (Corresponding author) Department of Geography, University of Cambridge CB2 3EN, UK. E-mail: wa12@cam.ac.uk

D. Hulme Institute for Development Policy and Management, University of Manchester, Manchester M13 9GH, UK. E-mail: david hulme@man. ac.uk

Revised manuscript accepted for publication 21 December 2000 built on. It is not a project or policy 'choice' that can be simply accepted or rejected. The key questions about community conservation are who should set the objectives for conservation policy on the ground and how should trade-offs between the diverse objectives of different interests be negotiated.

Keywords Africa, community conservation, conservation policy, development.

dilemmas and disappointments of conservation policy, particularly in the rural Third World.

The CC narrative maintains that conservation must be 'participatory', must treat protected area neighbours as 'partners', and preferably must be organized so that protected areas and species yield an economic return for local people and the wider economy, and contribute to sustainable livelihoods. Such initiatives have been labelled in many different ways, for example integrated conservation and development projects (ICDPs), community conservation programmes, collaborative or joint management ventures and community-based natural resource management (CBNRM).

Although clearly an alluring idea to policy-makers, community conservation is no panacea, and can be problematic in implementation. Critiques of ICDPs and 'conservation-with-development' projects now abound (e.g. Barrett \& Arcese, 1995; Oates, 1995; Ite, 1996; Noss, 1997; Wells et al., 1999). Criticism of the new conservation narrative is, however, both wider and less focused than these specific criticisms of ICDPs would imply. The attack comes from two very different positions. Some critics come from a tradition that is highly suspicious of the principles and practices of conservation, and detect in 'community conservation' a shallow and perhaps even deceitful facade designed to hide old-style preservation, with its harsh colonial legacy of policing, eviction and misanthropy (MacKenzie, 1987, 1989; Neumann, 1997). This view holds that, at best, community conservation is but a shallow imitation of a genuinely democratic conservation strategy, which would centre on (and be driven by) local peoples' ideas about and uses of nature. These critics, from a broadly human-rights position, are in unlikely alliance with other opponents of community conservation whose 
interests are very different, and who see in 'community conservation' a fatal weakening of resolve on the part of conservationists, and who fear that the preservation of species and ecosystems will be compromised by placing any measure of control in the hands of wildlife's greatest enemies - local people (e.g. Spinage, 1998). To these 'conservatives' or 'traditionalists', community conservation is an expensive and ineffective distraction from the established approaches to conservation, which are scientific management and policing.

\section{What is community conservation?}

Of course, here we have caricatured the pro- and anti-CC positions, and many contributors to conservation debates would probably identify a mixture of these ideas in their own thinking. This mixing of ideas is in many ways problematic: indeed, our experience (of our own thinking and that of others) suggests that many people thinking about and working in 'community conservation' are now confused about the terms used in the debate to such a degree as to make it difficult to discuss what should be done in general or in specific instances.

One way forward is to recognize that within the allencompassing narrative of CC lies a wide diversity of quite different kinds of projects. This diversity can be imagined as a continuum (Barrow \& Murphree, 2001). At one end lie initiatives designed to support national parks and their conservation objectives. Community conservation has replaced traditional 'protectionist' 'fines and fences' strategies (Barrett \& Arcese, 1995), around protected areas (e.g. Lindsay, 1987; Wells et al., 1992; Western \& Wright, 1994; Bergin, 2001). Such 'protected area outreach activities' (Barrow \& Murphree, 2001) have often been developed long after a protected area has been established, and are often expected to solve long-standing disputes about resource use and access rights.

In the middle of the community conservation continuum lie projects involving 'collaborative management' (Barrow \& Murphree, 2001) between state and local community (and sometimes the private sector). These take many forms, but have the eclectic and evolving characteristics of contemporary development strategies that argue for 'pluralist', partnership or interorganizational approaches (White \& Robinson, 1998; Robinson et al., 2000).

At the other end of the continuum lie initiatives aiming to achieve rural development through the use of wildlife or other living resources in places unconnected with protected areas. Here biodiversity conservation is a secondary benefit of a sustainable ecosystem management and resource use regime. Such projects are conventionally labelled CBNRM projects. The various experiments in southern Africa, particularly the Zimba- bwean CAMPFIRE programme, have been so extensively reported in the grey literature, and increasingly in the academic literature (e.g. Getz et al., 1999; Hasler, 1996; Murombedzi, 1999) that they have almost achieved iconic status among policy commentators, even (or especially) those who know little of the programme's context, methods and contemporary problems. CBNRM has become the focus of a great deal of attention by social scientists interested in the interface between social action and environmental management in wildlife, forestry and pastoralism (e.g. Leach et al., 1999).

Some contemporary CBNRM activities are generated within communities, and can reflect long-standing ideas about the values of ecosystems or habitats (for example their importance for cultural reasons) as well as intangible but still important contemporary values (e.g. watershed protection). The classic example of such initiatives are sacred groves, for example the makaya forest fragments of the Kenyan coast (Nyamweru, 1996). There are also long-established regimes of consumptive use of living plant resources from areas of unenclosed land in many parts of Africa, particularly in forest environments. Such use is in places being re-licensed in protected areas under the banner of 'community conservation', for example in Ugandan national parks (Cunningham, 1996; Wild \& Mutebi, 1996).

However, the renewed interest in CBNRM apparent among policy-makers in Africa in the 1990s led to externally generated and/or externally supported projects. These reflected the importance placed by policymakers on utilitarian, resource-based, revenue generation strategies. These have been seen as a response to the challenge to make conservation 'pay its way' by yielding cash revenues in areas where other forms of land use are vulnerable to drought and other hazards (Eltringham, 1994). CBNRM programmes are often referred to as 'conservation' strategies. This they are, in the narrow sense of the US 'progressive conservation movement' of the turn of the 19th century (Hays, 1959), because they are usually based in part at least on the sustainable harvest of living organisms or parts of organisms (fruit, bark, timber, skins, meat, etc.). CBNRM projects are not, however, primarily designed to achieve biodiversity preservation goals (although they may well do so as a byproduct, or as a means of achieving their primary goals).

\section{When community conservation is not the answer}

It might be concluded from our argument that if debate about community conservation becomes more exact in its definitions, and if due regard is paid to the different kinds of projects that exist under that heading, then some form of community conservation is likely to prove 
effective in most contexts.' A review of community conservation projects in Africa (Hulme \& Murphree, 2001a) suggests that this is not the case, but that in a number of circumstances no form of community conservation (beyond the principles of democratic government) will significantly contribute to the achievement of conservation goals. Of course, even in these cases, community conservation may well contribute to social or other goals, but that is a different argument.

A series of circumstances where CC seems not to be the answer in conservation policy are set out in Table 1, and discussed below. These include a series of circumstances where CC takes the form of CBNRM (numbers 1-4), and others relevant to PA outreach (numbers 5-10), although there can be overlap between these categories (Table 1).

\section{Where there is no wildlife resource that can yield a sustainable revenue flow}

In Africa, many $\mathrm{CC}$ activities are dependent on tourism or safari-hunting. Safari-hunting revenue is often dependent on a few species (in Africa, buffalo and elephant). Where these are absent, revenue opportunities are typically much less. Wildlife tourism is dependent on charismatic mammals (e.g. apes or the 'Big 5'), although the market for ornithological tours is growing. Although some regions in countries like those of southern Africa have good opportunities for CBNRM based on foreign visitors, others (for example those in West Africa) do not. The economic potential of ecotourism and safari hunting may be extended beyond the conventional savannah 'game' environment, for example in the Congo Basin, but the industry cannot survive without subsidy in such areas (Wilkie \& Carpenter, $1999 \mathrm{a}, \mathrm{b})$ and is dependent on political stability. Where $\mathrm{CC}$ activities are dependent on harvesting living resources for consumption or for local sale, the ecosystem's ability to provide a sustainable flow of benefits (monetary or otherwise) that is relevant to the needs of use-right holders and to the income from alternative uses of the land is also critical.

\section{Where the market for the wildlife resource is not sustainable}

It is not clear how large is global demand for hunting nor how elastic the demand is with respect to price. Hunting and wildlife viewing are dependent on the buoyancy of industrialized country economies, the continuance of cheap intercontinental flights (i.e. taxfree fuel), and the ability of governments to regulate wildlife-based tourism so that normal patterns of infrastructure senescence and resort decline are avoided. Ethical dimensions of trade in wildlife products in consumer countries may also limit the sustainability of wildlife marketing. Markets for harvested products for local sale can be sensitive to supply and demand, and sustainable levels of harvesting hard to identify and achieve (as the burgeoning urban market for bushmeat in some African countries demonstrates).

\section{Where the wildlife resource is, or becomes, insufficient to provide income to ensure the support of local actors}

Rural populations grow, yet the volume of harvestable wildlife (while fluctuating with ecosystem productivity)

Table 1 Conditions for effective community conservation (CC) initiatives

\begin{tabular}{|c|c|c|}
\hline Context & $\begin{array}{l}\text { Community conservation likely } \\
\text { to achieve both developmental } \\
\text { and conservation objectives }\end{array}$ & $\begin{array}{l}\text { Community conservation unlikely } \\
\text { to achieve both developmental } \\
\text { and conservation objectives }\end{array}$ \\
\hline 1. Wildlife resource harvest & Yields sustainable revenue flow & Does not yield sustainable revenue flow \\
\hline 2. Sustainability of market for wildlife resource & Sustainable & Not sustainable \\
\hline 3. Adequacy of wildlife resource & $\begin{array}{l}\text { Large enough to secure local support } \\
\text { for conservation action }\end{array}$ & $\begin{array}{l}\text { Not large enough to secure local } \\
\text { support for conservation action }\end{array}$ \\
\hline $\begin{array}{l}\text { 4. Range of biodiversity on which } \\
\text { economic benefits depend }\end{array}$ & High & Low \\
\hline 5. Loss of rights by local people & $\begin{array}{l}\text { Outweighed by economic benefits } \\
\text { and/or other incentives }\end{array}$ & $\begin{array}{l}\text { Not outweighed by economic } \\
\text { benefits or other incentives }\end{array}$ \\
\hline 6. Donor investment & Long-term & Short-term \\
\hline $\begin{array}{l}\text { 7. Influence of community conservation } \\
\text { rhetoric on conservation agency }\end{array}$ & $\begin{array}{l}\text { Ideology and practices of } \\
\text { conservation agency change }\end{array}$ & $\begin{array}{l}\text { Ideology and practices of } \\
\text { conservation agency do not change }\end{array}$ \\
\hline 8. Extent to which expectations are met & CC delivers benefits as planned & CC promises are not delivered \\
\hline $\begin{array}{l}\text { 9. Extent to which conservation agency } \\
\text { shares power with local people }\end{array}$ & $\begin{array}{l}\text { Genuine power sharing (in terms } \\
\text { of tenure security in resource access } \\
\text { and/or revenues and decision making) }\end{array}$ & Token power sharing \\
\hline 10. Non-monetary values of nature & Shared by local people & Not shared by local people \\
\hline
\end{tabular}


has an upper limit (Barrett \& Arcese, 1995). Price may increase with scarcity and innovative 'value added' products may be developed (Hulme \& Murphree, $2001 \mathrm{~b}$ ), but there is likely to be a ceiling on the revenue that can be generated by wildlife resources. Conservation strategies dependent on revenue sharing for their success will be vulnerable to declines in the relative size of the revenue pot and growth in the numbers needing to be served from it.

\section{Where the flow of community economic benefits require ecosystem services that can be supported by only some elements of existing biodiversity}

It is often argued that rural people are natural conservationists because they depend on ecosystem services and wildlife products. This may be true to an extent, but their natural resource needs may be supplied by a very narrow range of species: probably much narrower than the present complement of biodiversity. For example, tree cover might be necessary to prevent erosion, but highly diverse tree cover may not be required to achieve this objective. Gathering of forest vines, herding goats or hunting duiker may be easier and safer if lion, leopard or elephant are not present. Birds and butterflies may be of little interest. Management for high elephant or buffalo numbers and high trophy quality may be compatible with (or demand) habitat manipulation that actually reduces other forms of biodiversity. There may be some common interest between the maximization of the value of wildlife offtake and the preservation of biodiversity, but the two may well diverge.

\section{Where resentment about eviction or loss of rights in a protected area is profound}

Economists like to argue that every grievance has its price, but this is a very limited (and cynical) interpretation of the political response to state expropriation of resources. 'Benefit sharing' is often too small and too bureaucratically delivered to compensate local people permanently for loss of rights (Infield \& Adams, 1999; Hulme \& Infield, 2001). In situations where large numbers of people believe that they are the legitimate owners and users of a piece of land any opportunity to reoccupy it tends to be seized. In Uganda, at the end of the Civil War in 1986, those living in and around Lake Mburo National Park consciously set out to clear the area of wildlife to ensure that the government would lose interest in the area (Hulme \& Infield, 2001). At Mount Elgon National Park encroachment is a continuing issue, with many encroachers claiming that specific plots 'belong' to their families. Security of tenure, in land or resource use rights, is of fundamental importance to those who it is anticipated will willingly 'participate' in a conservation initiative.

\section{Where hopes are raised by donor investment that is not sustained}

USAID funding for CAMPFIRE has provided resources for local use (e.g. vehicles) that are potentially over and above the level that can be sustained in the long-term by hunting revenue in many areas. Local support for CAMPFIRE may be affected by the loss of this underpinning investment. Similarly, investment by conservation NGOs and donors in protected area 'support zones' (e.g. Mgahinga Gorilla National Park, Uganda) may achieve reasonable levels of support from local people, but in as much as this support is a response to investment, sustained investment may be necessary to maintain support (Infield \& Adams, 1999). However, in virtually all cases such funding is planned to cease within the time frame of a development project. Conservation benefits deriving from short-term project expenditure are only sustainable if either external funding continues to be pumped in, or if local revenues rise to replace it, and grow with local needs and aspirations (e.g. to match population growth, immigration and growing demands for income and services).

\section{Where the rhetoric of community conservation is not reflected in changed ideologies and practices on the part of the conservation agency}

Cloaking preservationist goals in a facade of participation is unlikely to be an effective strategy for conservation. Local people have long memories, and are often acute (and cynical) political analysts. Men in uniform who yesterday held guns are not credible agents for participatory approaches to conservation. The trust built up by effective efforts to work with local people can be rapidly destroyed by a single incidence of violence by PA staff (Hulme \& Infield, 2001).

8. Where hopes are raised by the rhetoric of community conservation that are dashed because the project fails to deliver the goods

Many CC projects are initiated externally. These present particular difficulties. Participatory planning is a process, and once begun, expectations (and often high expectations), which need to be honoured, are raised in local people. If conservation agencies are naive about the possibilities of 'win-win' outcomes from community conservation, and allow their optimism to be reflected in their statements (or the claims of local politicians) to 
communities, their protected areas are at risk if the community gains do not materialize. This is particularly a problem where 'participatory rural appraisal' (PRA) methods attempt to assess how people would respond to different kinds of benefits. Such surveys can be used not to explore planning options, but inappropriately to disseminate propaganda and promote positive attitudes to likely policy initiatives. An example is the effect of over-optimistic plans in a proposed 'support-zone' around Nigeria's Cross River National Park on community expectations: slow project implementation (as a result of donor reluctance to fund work in Nigeria because of human rights abuses) meant that the project stalled, the benefits failed to materialize, and local people thought they had been duped (Caldecott, 1996; Ite, 1996).

\section{Where the conservation agency sets unrealistic limits} on the extent to which they will share power

Participation is a process. Any engagement with the community to discuss what might be done must recognize the possibility that desired outcomes will clash with pre-determined conservation goals. Clearly such differences should be brought into the open, and can sometimes be reconciled, but if in fact the conservation agency starts from a position that they will not deviate from pre-determined conservation goals, 'community participation' is effectively reduced to propaganda and explanation. Where there is no genuine prospect of changing anything, attendance at meetings to discuss conservation is unlikely to be attractive to local people (although of course, if people are paid for coming to meetings they may welcome them, and if community leaders alone are co-opted into such committees they may well promise acquiescence, but without knowing how far they can deliver appropriate responses from others). The extent to which there is transparency, equity and trust within local communities is important in determining whether outsiders' initiatives will be widely understood, and acceptable community responses formulated. Divisions on the basis of ethnicity, gender, age or wealth add enormously to the challenge of 'participatory' planning.

10. Where local people do not share the non-monetary values placed on species or ecosystems by conservation planners, and where conservation education cannot persuade them to do so

There is a widespread belief among conservationists that wildlife is beautiful, and the preservation of biodiversity morally right. They believe that education (e.g. films, talks by game guards, visits by schoolchil- dren to protected areas) will persuade rural people of this. The adoption of values is highly complex, and this simplistic model of a 'knowledge gap' about wildlife is unrealistic. The attitudes of local people to what conservationists call 'wildlife' is complex, and goes well beyond the merely material analysis of conventional economists and the moral analysis of conservationists. People may place particular non-monetary values on some or all wild species in a particular place, or value a piece of habitat (for example a forest) for various clear but not financial reasons. However, these valuations are often very different from those imagined by conservationists who hope to identify them and build bridges to their own values and ideas (e.g. Sharpe, 1998). Local ideas about nature are unlikely to be profoundly affected by the repetition of sermons by game guards or others. If the achievement of conservation goals is believed to depend on a value shift through educational inputs, particularly if the shift is expected to be rapid, it is unlikely to be successful.

\section{Does community conservation 'work'?}

The idea that there is a 'new conservation' (Hulme \& Murphree, 1999) is widely accepted, and it is obvious that battle has been joined, between supporters and opponents of a 'participatory' or 'community' approach to conservation, as to whether the approach 'works'. We believe this debate is premature.

Any debate about whether community approaches to conservation 'work' depends on the frame of reference used. To a preservationist, they would only work if they made biodiversity preservation objectives achievable, or more likely to be achievable, or achievable more quickly, cheaply or permanently. There is a temptation to see the aim of such community conservation as to keep a truculent populace quiet so the serious business of science-based ecosystem management can proceed unhindered. This is a very different objective from that of an NGO committed to opening up those 'scientific' decisions to democratic discussion by local people, and promoting access to a protected area for people who are excluded. The former 'preservationist' approach to community conservation views it instrumentally, as a potentially better way of delivering pre-established conservation goals. The latter approach views community conservation as a process, building new patterns of power to make decisions about human uses of wildlife based on a change in relative power and de jure rights between government and local people. Both approaches might legitimately claim the label of 'community conservation', but clearly they mean very different things by it. Whatever their aims, both might properly be approached through 'consultation' with local people 
and in a spirit of open government to explain and seek support for their objectives. Unless the criteria for judging the success of community conservation approaches are made clear (and perhaps standardized), then judgement will be both contentious and of limited value. Both approaches are very different from conservation as something chosen and practised by local people themselves: decisions by the community, not for the community or about the community.

Community conservation comes in such varied forms that it must be recognized not as a single approach (or a specific policy choice) but as representing a range of options. The notion that $\mathrm{CC}$ can be assessed and validated or invalidated as a policy is flawed. Community conservation is an evolving concept and practice, so learning why it has or has not 'worked', and feeding such lessons into future practice, should be the pursuit of analysts, not simply rejecting or accepting it. There is a need for much more extensive and thorough critique of conservation policy in practice. At the same time, the contemporary experience of community conservation in Africa clearly demonstrates that attempts to present community conservation as a strategy that achieves both 'community' development needs and biodiversity preservation objectives in full must be dismissed.

Although some political philosophies would challenge it, the principle that conservation policy, like other forms of government action, should be built on consultation with citizens (or, more simply, on the principle of democratic and open government), is fundamental to Western ideas of democratic governance. Government should be open, accountable and devolved, but this does not mean that governments cannot do things to which some citizens object. Conservation programmes are, like other government activities such as dams, mechanized agriculture projects or military spending (or nuclear power stations or motorways in industrialized economies), likely to be unpopular either locally (the 'not in my backyard' factor) or with certain interest groups in society. Liberal commentators on development have frequently criticised such initiatives for their adverse socioeconomic impacts. Criticisms focus on three issues: costs may outweigh benefits, costs may be borne by certain social groups (e.g. poor rural communities) who are not compensated, and some projects may be planned and imposed without consultation. All these criticisms can be made of conservation programmes in developing countries, and need to be debated (sometimes urgently). It is right that governments (and NGOs) should be called to account for their policies on conservation, should have to explain and build legitimacy for them, and should seek to establish fair regimes for compensating citizens who suffer hardship for the greater good. In that sense, the notion that conservation should be done 'with the community' is surely right, at least in terms of ideas about good governance held in Western industrialized democracies.

\section{Conclusions}

At best, CC permits the identification of positions where workable trade-offs might be achieved between conservation and development objectives. Such positions will be dynamic and must be renegotiated over time. Only in rare contexts - high value tourism, safari hunting in agro-ecologically marginal lands with low populations, situations where human activity has a low impact and is not causing rapid environmental change - will trade-offs between objectives not be significant.

Love it or hate it, community conservation (in one guise or another) is here to stay. Conceptually, conservation may be presented as a moral choice - the imperative to conserve or the imperative to let local people manage and use natural resources as they think most appropriate. In practice, conservation policy has to address both sides of this equation. It demands a search for effective means of negotiating how to trade-off the goals of improving livelihoods while conserving wildlife.

The key question for conservation planners is therefore not whether conservation should be pursued with local people or in the teeth of their opposition. The answer to this is obvious, on both humanitarian and pragmatic grounds, and is attested to by the many studies of expensive policy failure where conservation has been pursued against the wishes and needs of local people. The real issue is not whether conservation should be done with people, but how. Conservation cannot effectively be pursued by the state or 'the community' alone: they have to work together, and new institutional frameworks are likely to be needed to enable them to do so.

The most important questions to be asked about community conservation are therefore who should set the objectives for conservation policy on the ground and how should trade-offs between the diverse objectives of different interests (e.g. biodiversity preservation and local livelihoods) be negotiated. The answers to both are likely to vary as different actors, different kinds of conservation resources, and different economic imperatives, come into play. Conservation, like development, is highly political, and debate about what should be done and how are inevitable. The challenge of community conservation is to ask who should be part of that debate in particular places and at particular times. 


\section{Acknowledgements}

This article draws on work funded by the Global Environmental Change Programme of the Economic and Social Research Council entitled Community Conservation in Africa: Principles and Comparative Practice (L 320 25321) and reflects numerous insights gained through discussion with members of that project team. We would like to thank Ed Barrow, Mark Infield, Marshall Murphree, Jon Hutton, Lucy Welford and Lee Risby for their help in formulating arguments, and our three referees for their comments and advice.

\section{References}

Adams, W.M. \& Hulme, D. (1998) Conservation and Communities: Changing Narratives, Policies and Practices in African Conservation. Community Conservation in Africa: Principles and Comparative Practice. Discussion Paper no. 4, IDPM. University of Manchester, Manchester.

Adams, W.M. \& Hulme, D. (2001) Conservation and community: changing narratives, policies and practices in African conservation. In African Wildife and Livelihoods: The Promise and Performance of Community Conservation (eds D. Hulme \& M. Murphree), pp. 9-23. James Currey, Oxford and Heinemann, New Hampshire.

Barrett, C.S. \& Arcese, P. (1995) Are integrated conservationdevelopment projects (ICDPs) sustainable? On the conservation of large mammals in Sub-Saharan Africa. World Development, 23, 1073-1084.

Barrow, E. \& Murphree, M. (2001) Community conservation from concept to practice: a framework. In African Wildlife and Livelihoods: The Promise and Performance of Community Conservation (eds D. Hulme \& M. Murphree), pp. 24-37. James Currey, Oxford and Heinemann, New Hampshire.

Bergin, P. (2001) Reforming a conservation bureaucracy in Tanzania: TANAPA and community conservation. In African Wildlife and Livelihoods: The Promise and Performance of Community Conservation (eds D. Hulme \& M. Murphree), pp. 88-105. James Currey, Oxford and Heinemann, New Hampshire.

Caldecott, J. (1996) Designing Conservation Projects. Cambridge University Press, Cambridge.

Cunningham, A.B. (1996) People, Park and Plant Use: Recommendations for Multiple-Use Zones and Development Alternatives around Bwindi Impenetrable National Park, Uganda. People and Plants Working Paper 4, UNESCO, Paris.

Eltringham, S.K. (1994) Can wildlife pay its way? Oryx, 28, 163-168.

Getz, W.M., Fortmann, L., Cumming, D., et al. (1999) Sustaining natural and human capital: villagers and scientists. Science, 283, 1855-1856.

Ghimire, K.B. \& Pimbert, M.P. (eds) (1996) Social Change and Conservation. Earthscan, London.

Hasler, R. (1996) Agriculture, Foraging and Wildlife Resource Use in Africa. Kegan Paul International, London.

Hays, S.P. (1959) Conservation and the Gospel of Efficiency: The Progressive Conservation Movement 1890-1920. Harvard University Press, Harvard, MA.
Hulme, D. \& Infield, M. (2001) Community conservation, reciprocity and park-people relationships: a study of Lake Mburo National Park, Uganda. In African Wildlife and Livelihoods: The Promise and Performance of Community Conservation (eds D. Hulme \& M. Murphree), pp. 106-130. James Currey, Oxford and Heinemann, New Hampshire.

Hulme, D. \& Murphree, M. (1999) Communities, wildlife and the 'new conservation' in Africa. Journal of International Development, 11, 277-286.

Hulme, D. \& Murphree, M. (eds) (2001a) African Wildlife and Livelihoods: The Promise and Performance of Community Conservation. James Currey, Oxford and Heinemann, New Hampshire.

Hulme, D. \& Murphree, M. (2001b) Community conservation as policy: promise and performance. In African Wildife and Livelihoods: The Promise and Performance of Community Conservation (eds D. Hulme \& M. Murphree), pp. 280297. James Currey, Oxford and Heinemann, New Hampshire.

Inamdar, A., de Jode, H., Lindsay, K. \& Cobb, S. (1999) Capitalising on Nature: protected area management. Science, 283, 1856-1857.

Infield, M. \& Adams, W.M. (1999) Institutional sustainability and community conservation: a case study from Uganda. Journal of International Development, 11, 305-315.

Ite, U.E. (1996) Community perceptions of the Cross River National Park, Nigeria'. Environmental Conservation, 23, 351-357.

Leach, M. \& Mearns, R. (1996) The Lie of the Land: Challenging Received Wisdom on the African Environment. Heinemann and James Currey, London.

Leach, M., Mearns, R. \& Scoones, I. (1999) Environmental entitlements: dynamics and institutions in community-based natural resource management. World Development, 27, 225-247.

Leader-Williams, N. \& Albon, S. (1988) Allocation of resources for conservation. Nature, 336, 353.

Lindsay, W.K. (1987) Integrating parks and pastoralists: some lessons from Amboseli. In Conservation in Africa: People, Policies and Practice (eds D.M. Anderson \& R.H. Grove), pp. 149-168. Cambridge University Press, Cambridge.

MacKenzie, J.M. (1987) Chivalry, social Darwinism and ritualised killing: the hunting ethos in central Africa up to 1914. In Conservation in Africa: People, Policies and Practice (eds D.M. Anderson \& R.H. Grove), pp. 41-62. Cambridge University Press, Cambridge.

MacKenzie, J.M. (1989) The Empire of Nature: Hunting, Conservation and British Imperialism. University of Manchester Press, Manchester.

Murombedzi, J.C. (1999) Devolution and stewardship in Zimbabwe's CAMPFIRE Programme. Journal of International Development, 11, 287-294.

Neumann, R.P. (1997) Primitive ideas: protected area buffer zones and the politics of land in Africa. Development and Change, 28, 559-582.

Neumann, R.P. (1998) Imposing Wilderness: Struggles Over Livelihood and Nature Preservation in Africa. University of California Press, Berkeley.

Norton-Griffiths, M. \& Southey, C. (1995) The opportunity costs of biodiversity conservation in Kenya. Ecological Economics, $12,125-139$ 
Noss, A.J. (1997) Challenges to nature conservation with community development in central African forests. Oryx, 31, 180-188.

Nyamweru, C. (1996) Sacred groves threatened by development: the Kaya forests of Kenya. Cultural Survival Quarterly. Fall 1996, 20, 19-21.

Oates, J.F. (1995) The dangers of conservation by rural development - a case study from the forests of Nigeria. Oryx, 29, $115-122$.

Robinson, D., Hewitt, T. \& Harriss, J. (2000) Managing Development. Sage, London.

Sharpe, B. (1998) First the forest': conservation, 'community' and 'participation' in South-West Cameroon. Africa, 68, 25-45.

Spinage, C. (1998) Social change and conservation. Oryx, 32, 265-276.

Wells, M., Brandon, K. \& Hannah, L. (1992) People and Parks: Linking Protected Areas with Local Communities. World Bank, Washington DC.

Wells, M., Guggenheim, S., Khan, A., Wardojo, W. \& Jepson, P. (1999) Investing in Biodiversity: A Review of Indonesia's Integrated Conservation and Development Projects. World Bank, Washington DC.

Western, D. \& Wright, M. (1994). Natural Connections. Island Press, Washington DC.

White, G. \& Robinson, M. (1998) Towards synergy in social provision: civic organisations and the state. In Beyond the New Public Management (eds M. Minogue, C. Polidano \& D. Hulme), pp. 94-116. Edward Elgar, Cheltenham.
Wild, R.G. \& Mutebi, J. (1996) Conservation through Community Use of Plant Resources: Establishing Collaborative Management at Bwindi Impenetrable and Mgahinga Gorilla National Parks, Uganda. People and Plants Working Paper 5, UNESCO, Paris. Wilkie, D.S. \& Carpenter, J.F. (1999a) Can nature tourism help finance protected areas in the Congo Basin? Oryx , 33, 332-338.

Wilkie, D.S. \& Carpenter, J.F. (1999b) The potential role of safari hunting as a potential source of revenue for protected areas in the Congo Basin? Oryx, 33, 338-345.

\section{Biographical sketches}

Bill Adams is Reader in the Geography of Conservation and Development at the University of Cambridge, where he has been teaching since 1984 . He has worked on conservation and rural development in Nigeria, Kenya, Tanzania and Uganda.

David Hulme is Professor of Development Studies at the Institute for Development Policy and Management, University of Manchester. He has worked extensively on rural development and poverty-reduction strategies in South Asia, Africa and the Pacific. His recent work has included research on local environmental management in Africa. 